DOI: $10.19195 / 0137-1134.117 .9$

\author{
JUSTYNA ŚWIĄTEK-RUDOMAN \\ ORCID: 0000-0001-8752-1279 \\ Uniwersytet Gdański
}

\title{
UBEZPIECZENIE SPOŁECZNE TWÓRCÓW I ARTYSTÓW - WYBRANE ZAGADNIENIA
}

\begin{abstract}
Abstrakt: Działalność twórcza i artystyczna w kontekście podlegania ubezpieczeniom społecznym budzi wiele kontrowersji. Wynika to z jej specyfiki związanej z nieregularnością pracy i dochodów przy obciążeniach składkowych takich jak u przedsiębiorców. Autorka analizuje i ocenia obecnie obowiązujące uregulowania prawne związane z ubezpieczeniem społecznym twórców i artystów, a zwłaszcza rolę decyzji Komisji do Spraw Zaopatrzenia Emerytalnego Twórców ustalającej, od kiedy taka działalność jest prowadzona i jej wpływ na powstanie obowiązku ubezpieczeniowego i prawa do świadczeń. Ponadto przedstawia postulowane i proponowane zmiany w zakresie objęcia tej grupy zawodowej odrębnym systemem ubezpieczenia społecznego zakładającym stworzenie odpowiednich mechanizmów wsparcia, co pozwoli tym osobom realnie uczestniczyć w systemie.
\end{abstract}

Słowa kluczowe: ubezpieczenie społeczne, twórcy i artyści, odrębny system ubezpieczenia

\section{WPROWADZENIE}

Zasady podlegania ubezpieczeniom społecznym przez twórców i artystów od lat budzą wiele kontrowersji i wywołują rozbieżności nie tylko w doktrynie i orzecznictwie, lecz także w gronie środowisk artystycznych. Wynika to ze specyfiki działalności tej grupy zawodowej w stosunku do innych osób wykonujących pozarolniczą działalność gospodarczą. Przedmiotem niniejszego opracowania jest przedstawienie wybranych zagadnień z zakresu prawa ubezpieczenia społecznego twórców i artystów ze szczególnym uwzględnieniem wątpliwości związanych z ich aktualnym statusem, decyzją komisji ustalającej datę rozpoczęcia tej działalności w zakresie powstania obowiązku ubezpieczenia społecznego oraz postulowanymi i proponowanymi zmianami w zakresie objęcia tych osób odrębnym systemem ubezpieczenia społecznego. 


\section{DZIAŁALNOŚĆ TWÓRCZA I ARTYSTYCZNA}

W przepisie art. 8 ust. 7 i 8 ustawy z dnia 13 października 1998 roku o systemie ubezpieczeń społecznych (dalej: u.s.u.s.) ${ }^{1}$ zawarto definicje legalne pojęć „twórca” i „artysta”. Za twórcę uważa się osobę, która tworzy dzieła w zakresie architektury, architektury wnętrz, architektury krajobrazu, urbanistyki, literatury pięknej, sztuk plastycznych, muzyki, fotografiki, twórczości audiowizualnej, choreografii i lutnictwa artystycznego oraz sztuki ludowej, będące przedmiotem prawa autorskiego. Z kolei „artysta” to osoba zarobkowo wykonująca działalność artystyczną w dziedzinie sztuki aktorskiej i estradowej, reżyserii teatralnej i estradowej, sztuki tanecznej i cyrkowej oraz w dziedzinie dyrygentury, wokalistyki, instrumentalistki, kostiumografii, scenografii, a także w dziedzinie produkcji audiowizualnej reżyser, scenarzysta, operator obrazu i dźwięku, montażysta i kaskader. Jak widać, katalog osób zaliczanych do tej kategorii ubezpieczonych jest bardzo szeroki i zróżnicowany pod względem rodzaju wykonywanej aktywności zawodowej.

Specyfika działalności twórców i artystów niewątpliwie wiąże się z indywidualnym i twórczym charakterem ich dzieł. $Z$ uwagi na samodzielność i niezależność procesu twórczego trudno doszukiwać się tu cech typowego podporządkowania pracowniczego, co powoduje, że pozostawanie w relacjach pracownik-pracodawca nie jest co do zasady adekwatną formą świadczenia przez nich pracy. Nie oznacza to jednak, że część z tych osób nie pozostaje w relacjach pracowniczych. $Z$ punktu widzenia podlegania ubezpieczeniom emerytalnym i rentowym twórców i artystów zakwalifikowano w poczet jednej z kategorii osób wykonujących „pozarolniczą działalność gospodarczą" (art. 8 ust. 6 u.s.u.s.). Pojęcie to nie zostało jednak w tej ustawie zdefiniowane. W doktrynie słusznie uznaje się, że jest ono terminem szerszym, niż określona $\mathrm{w}$ ustawie z dnia 6 marca 2018 roku Prawo przedsiębiorców działalność gospodarcza ${ }^{2}$, która charakteryzuje się profesjonalnością, samodzielnością, zarobkowym charakterem, zorganizowaniem oraz ciągłością ${ }^{3}$. Oceniając jednak sposób wykonywania pracy przez tę grupę osób, okazuje się, że ich działaniom wielokrotnie nie można przypisać cech zorganizowania i ciągłości, a także trudno mówić o regularności dochodów. To powoduje, że środowiska twórcze i artystyczne od lat zgłaszają postulaty stworzenia odrębnego systemu zabezpieczenia społecznego tych osób, dostosowanego do realiów ich pracy i możliwości ponoszenia obciążeń fiskalnych.

1 Tekst jedn. Dz.U. z 2019 r. poz. 300 z późn. zm.

2 Dz.U. z 2018 r. poz. 646, z późn. zm. Zgodnie z art. 3 tej ustawy działalnością gospodarczą jest zorganizowana działalność zarobkowa, wykonywana we własnym imieniu w sposób ciągły.

3 Zwracała na to uwagę B. Gudowska na tle wcześniej obowiązującej ustawy z dnia 2 lipca 2004 roku o swobodzie działalności gospodarczej (Dz.U. z 2017 r. poz. 2168 z późn. zm.). B. Gudowska, [w:] Ustawa o systemie ubezpieczeń spotecznych. Komentarz, red. B. Gudowska, J. Strusińska-Żukowska, Warszawa 2011, s. 105. 


\section{SPECYFIKA UBEZPIECZENIA SPOŁECZNEGO TWÓRCÓW I ARTYSTÓW}

Przed wejściem w życie ustawy z dnia 13 października 1998 roku o systemie ubezpieczeń społecznych, to jest przed 1 stycznia 1999 roku, ubezpieczenie społeczne twórców było unormowane ustawą z dnia 27 września 1973 roku o zaopatrzeniu emerytalnym twórców i ich rodzin ${ }^{4}$. Na mocy obecnie obowiązującej u.s.u.s. twórcy oraz artyści znaleźli się wśród podmiotów, które obowiązkowo podlegają ubezpieczeniom emerytalnym, rentowym oraz wypadkowemu (art. 8 ust. 6 pkt 2 u.s.u.s. $i$ art. 12 ust. 1 u.s.u.s.). Zgodnie z art. 13 pkt 4 u.s.u.s. z tytułu wykonywanej pozarolniczej działalności gospodarczej podlegają im od dnia jej rozpoczęcia do dnia jej zaprzestania. W zakresie ubezpieczenia chorobowego podlegają mu na zasadzie dobrowolności (art. 11 ust. 2 u.s.u.s.).

Co ciekawe, samo wykonywanie działalności twórczej lub artystycznej nie wystarcza do powstania obowiązku ubezpieczenia społecznego z tego tytułu. Prowadzona przez zainteresowanego działalność musi zostać uznana za taką działalność w specjalnym trybie i dopiero wtedy stanowi tytuł do objęcia ubezpieczeniem społecznym. Następuje to według uznania Komisji do Spraw Zaopatrzenia Emerytalnego Twórców (dalej: Komisja) działającej przy Ministrze Kultury i Dziedzictwa Narodowego. Zadania, skład i zasady działania Komisji określono w rozporządzeniu Ministra Kultury i Sztuki z dnia 9 marca 1999 roku w sprawie powołania Komisji do Spraw Zaopatrzenia Emerytalnego Twórców oraz szczegółowego określenia jej zadań, składu i trybu działania ${ }^{5}$. Głównym zadaniem Komisji jest nie tylko uznawanie działalności za twórczą lub artystyczną, lecz także ustalenie daty jej rozpoczęcia. Zgodnie z $\S 4$ wspomnianego rozporządzenia następuje to jednak na wniosek osoby zainteresowanej. Do wniosku należy dołączyć dokumenty potwierdzające czas trwania i charakter działalności twórczej lub artystycznej, która jest wykonywana na podstawie umowy o pracę, umowy o dzieło, umowy zlecenia, a także katalogów z wystaw, recenzji, otrzymanych nagród i wyróżnień. Ponadto należy dołączyć dyplom ukończenia szkoły artystycznej odpowiedniego typu lub szkoły wyższej na kierunku odpowiednim do wykonywanej aktywności albo zaświadczenia o nabyciu $\mathrm{w}$ drodze praktyki umiejętności zawodowych wydane przez właściwe stowarzyszenie zrzeszające środowisko artystyczne (§ 2 rozporządzenia). O objęciu ubezpieczeniem twórcy czy artysty nie decyduje forma wykonywania zawodu, nawet gdy w działalności osoby przeważa pierwiastek komercyjny nad twórczym, na przykład artyści rzemieślnicy czy zleceniobiorcy piszący scenariusze reklam na zlecenie, ale weryfikacja w odpowiednim trybie przed odpowiednim organem danej działalności jako twórczej lub artystycznej.

Komisja zwołuje się ad hoc, w miarę potrzeby zawiadamiając członków co najmniej 14 dni przed terminem posiedzenia. Orzeka w składzie co najmniej trzech członków stałych oraz jednego przedstawiciela zainteresowanego stowarzyszenia spośród członków niestałych. Decyzje zapadają większością głosów. W przypad- 
ku równości głosów decydujące znaczenie ma stanowisko przewodniczącego. Od decyzji Komisji przysługuje odwołanie do ministra właściwego do spraw kultury $\mathrm{w}$ terminie dwóch miesięcy od daty doręczenia decyzji.

Zgodnie z przepisem art. 36 ust. 4 a u.s.u.s. w ciągu siedmiu dni od otrzymania decyzji Komisji ustalającej datę rozpoczęcia wykonywania działalności twórczej i artystycznej należy zgłosić się do ubezpieczeń społecznych. Z uwagi na treść tego przepisu należy zastanowić się nad charakterem prawnym decyzji Komisji w przedmiocie objęcia obowiązkiem ubezpieczenia, a także wpływem daty wydania tej decyzji na okres podlegania ubezpieczeniom emerytalno-rentowym przez wnioskodawcę.

Po pierwsze, decyzja Komisji, która wydawana jest w ramach uznania administracyjnego, ma charakter deklaratywny, potwierdza bowiem jedynie fakt wykonywania przez daną osobę działalności twórczej lub artystycznej i ustala datę rozpoczęcia tej działalności. Komisja nie ma jednak obowiązku informowania organu rentowego $\mathrm{w}$ trybie art. 37 ust. 2 u.s.u.s., przepis ten dotyczy bowiem konieczności doręczania właściwym jednostkom Zakładu Ubezpieczeń Społecznym kopii uprawnień wydawanych osobom fizycznym przez organy uprawnione do wydawania uprawnień na prowadzenie działalności pozarolniczej. Decyzja Komisji nie jest jednak zezwoleniem na wykonywanie tej działalności 6 . Działanie na wniosek danej osoby czyni to ubezpieczenie $\mathrm{w}$ zasadzie ubezpieczeniem na zasadzie dobrowolności, co powoduje wątpliwość z zakwalifikowaniem twórców i artystów do kręgu osób obowiązkowo podlegających ubezpieczeniom emerytalnym i rentowym. Obowiązkowość ubezpieczenia społecznego wynika co do zasady z przepisów prawa i nie jest uzależniona od woli ubezpieczonego lub organu rentowego. Dochodzi w tym przypadku, co zasygnalizowano w doktrynie, do pewnej niekoherentności przepisów rozporządzenia z przepisami ustawowymi, co wymagałoby interwencji ustawodawcy w postaci dostosowania przepisu art. 6 ust. 1 pkt 5 u.s.u.s. w zw. z art. 8 ust. 9 u.s.u.s. ${ }^{7}$ Wydaje się, że ubezpieczenie społeczne tej grupy zawodowej $\mathrm{w}$ obecnie funkcjonującym modelu ma postać zbliżoną raczej do ubezpieczenia na wniosek, dlatego że koniecznym etapem poprzedzającym ustalenie obowiązku ubezpieczenia z tytułu działalności twórczej lub artystycznej jest nie tylko zgłoszenie się do Komisji, lecz także po jej decyzji zgłoszenie się do ubezpieczenia społecznego przez wnioskodawcę.

Odnośnie do drugiego z zagadnień, które wywołuje wiele rozbieżności w wykładni przepisów obowiązującego prawa, o czym świadczą liczne odwołania od decyzji organów rentowych, należy stwierdzić, że samo potwierdzenie, że dana osoba zostaje uznana przez Komisję za twórcę lub artystę, nie oznacza automa-

6 Wyrok Sądu Apelacyjnego w Łodzi z dnia 26 stycznia 2018 roku, III AUa 418/17, OSAŁ 2018/1/79, LEX nr 2520898 (dostęp: 28.03.2019).

7 Tak M. Zieleniecki, Zakres podmiotowy ubezpieczenia społecznego, [w:] Ubezpieczenia spoteczne dawniej $i$ dziś. $W$ 80-lecie uchwalenia ustawy o ubezpieczeniu spotecznym, red. Ł. Kucharczyk-Rok, O. Rawski, A. Żołna, Wrocław 2013, s. 53-54. 
tycznie uzyskania prawa do świadczeń emerytalno-rentowych. Trzeba jeszcze wykazać, że opłacone zostały w tym czasie składki na ubezpieczania społeczne ${ }^{8}$. W tym miejscu należy pochylić się nad treścią art. 6 ust. 2 pkt 9 lit. a i b ustawy z dnia 17 grudnia 1998 roku o emeryturach i rentach z Funduszu Ubezpieczeń Społecznych (dalej: u.F.U.S.) ${ }^{9}$, zgodnie z którą za okresy składkowe uwzględniane przy ustalaniu prawa do emerytury (renty) uważa się również przypadające przed dniem 15 listopada 1991 roku okresy wykonywania działalności twórczej lub artystycznej na obszarze Państwa Polskiego objętej obowiązkiem ubezpieczenia społecznego, za które opłacono składkę na ubezpieczenia społeczne lub w których ubezpieczony był zwolniony od opłacania składki oraz działalności artystycznej (twórczej), przypadającej przed dniem 1 stycznia 1974 roku, uznanej przez Komisję do Spraw Zaopatrzenia Emerytalnego Twórców, działającą przy ministrze właściwym do spraw kultury, pod warunkiem że twórca lub artysta opłacał składki na ubezpieczenie społeczne po dniu 31 grudnia 1973 roku. W orzecznictwie podkreślono, że przy ustaleniu okresów składkowych twórców uwzględnia się okresy działalności twórczej przypadającej przed 1 stycznia 1974 roku, uznane przez Komisję za twórcze, nawet gdy za pewien okres po 31 grudnia 1973 roku twórca miał przerwy w opłacaniu składek. Ku takiemu wnioskowi skłania wykładnia literalna treści obecnie obowiązującego przepisu art. 6 ust. 2 pkt 9 lit. b in fine, który nie zawiera już wymogu ciągłości w opłacaniu składek po tej dacie ${ }^{10}$. Te okresy przerwy w opłacaniu składek nie zostają wówczas zaliczone do stażu ubezpieczeniowego. Nie pozbawia to jednak danej osoby możliwości zaliczenia reszty okresów działalności twórczej, za które składki zostały uregulowane.

Konkludując, należy stwierdzić, że o ile przed dniem 1 stycznia 1974 roku rzeczywiście nie istniał obowiązek opłacania składek na ubezpieczenie społeczne twórców, o tyle okresy wykonywania działalności twórczej lub artystycznej przed tą datą są traktowane w myśl art. 6 ust. 2 pkt 9 lit. b u.F.U.S. jako fikcyjne (bez opłaconej składki) okresy składkowe, tylko wówczas gdy, po pierwsze, zostały uznane przez Komisję za okresy prowadzenia takiej działalności oraz, po drugie, twórca lub artysta po dniu 31 grudnia 1973 roku opłacał składki z tytułu jej wykonywania ${ }^{11}$.

Zgodnie z art. 47 ust. 1a u.s.u.s. twórcy i artyści przesyłają deklaracje rozliczeniowe i imienne raporty miesięczne oraz opłacają składki za okres wykonywania działalności twórczej lub artystycznej przed dniem wydania decyzji Komisji

8 Także na podstawie poprzednio obowiązującej ustawy z dnia 27 września 1973 roku o zaopatrzeniu emerytalnym twórców i ich rodzin obowiązek ten istniał. Zgodnie bowiem z art. 9 ustawy: „Za okresy działalności twórczej uprawniającej do świadczeń na podstawie ustawy uważa się okresy tej działalności, za które zostały opłacone składki oraz okresy, w których twórca został zwolniony od ich opłacania".

9 Dz.U. z 2018 r. poz. 1270 z późn. zm.

10 Wyrok Sądu Apelacyjnego w Łodzi z dnia 20 kwietnia 2012 roku, III AUa 1212/11, OSAŁ 2012/1/4, LEX nr 1168817 (dostęp: 28.03.2019).

11 Wyrok Sądu Najwyższego z dnia 8 listopada 2012 roku, II UK 95/12, OSNP 2013/1920/234, LEX nr 1238102 (dostęp: 28.03.2019). 
w terminie opłacania składek za miesiąc, w którym otrzymali decyzję. Co istotne, możliwość jednorazowego zapłacenia składek przez twórców i artystów za okres przed otrzymaniem decyzji Komisji, a po rozpoczęciu działalności twórczej dotyczy jedynie składek nieprzedawnionych. Nie ma bowiem podstaw prawnych do konstruowania po stronie organu rentowego obowiązku przyjęcia przedawnionych składek, gdy zobowiązania składkowe już wygasły. Twórca jak każdy inny płatnik składek jest obowiązany zgłosić się do ubezpieczeń społecznych i opłacać należne składki w terminie ich wymagalności, co znajduje potwierdzenie w ugruntowanym orzecznictwie sądowym ${ }^{12}$.

Twórcy podlegają obowiązkowi ubezpieczenia społecznego w zakresie wysokości odprowadzanych składek tak jak przedsiębiorcy. Nie korzystają jednak $\mathrm{z}$ takich samych ulg. Zgodnie z nowym przepisem art. 8 ust. 6a u.s.u.s. za osobę prowadzącą pozarolniczą działalność nie uważa się w rozumieniu tej ustawy osoby fizycznej, o której mowa w art. 18 ust. 1 ustawy z dnia 6 marca 2018 roku Prawo przedsiębiorców ${ }^{13}$. Przepis ten reguluje materię tak zwanej ulgi na start, która jest niezwykle ważna dla młodych ludzi zakładających pozarolniczą działalność gospodarczą, umożliwia im bowiem niepodleganie obowiązkowym ubezpieczeniom społecznym przez sześć miesięcy od dnia rozpoczęcia po raz pierwszy w życiu tej działalności lub podjęcia jej po co najmniej sześćdziesięciomiesięcznej przerwie od dnia jej ostatniego zawieszenia lub zakończenia. Z kolei uprawnienie polegające na prawie do preferencyjnych składek na ubezpieczenia społeczne odprowadzanych od zadeklarowanej kwoty nie niższej niż 30\% wynagrodzenia minimalnego przez pierwsze 24 miesiące od rozpoczęcia prowadzenia działalności po raz pierwszy lub po sześćdziesięciomiesięcznej przerwie przysługuje ubezpieczonym, o których mowa w art. 8 ust. 6 pkt 1 u.s.u.s., a więc jedynie osobom prowadzącym pozarolniczą działalność gospodarczą na podstawie przepisów ustawy Prawo przedsiębiorców lub innych przepisów szczególnych ${ }^{14}$. Zgodnie z wykładnią literalną twórcy i artyści określeni w art. 8 ust. 6 pkt 2 nie korzystają $\mathrm{z}$ tej ulgi. Trudno znaleźć uzasadnienie wykluczenia tej grupy z tego przywileju. Rozwiązanie wyłączające prawo twórców do skorzystania z preferencyjnej stawki na i tak bardzo trudnym rynku nie zachęca adeptów sztuk pięknych do rozpoczynania działalności gospodarczej w tej formie prawnej. W związku z tym, żeby skorzystać z ulgi, nie starają się o uzyskanie statusu twórcy i świadczą różnego rodzaju działalności jako przedsiębiorcy.

12 Wyrok Sądu Apelacyjnego w Łodzi z dnia 2 marca 2017 roku, III AUa 534/16, LEX nr 2278244; wyrok Sądu Apelacyjnego w Szczecinie z dnia 3 grudnia 2015 roku, III AUa 544/15, LEX nr 2086549; wyrok Sądu Apelacyjnego w Szczecinie z dnia 9 czerwca 2015 roku, III AUa 736/14, LEX nr 2100042 (dostęp: 28.03.2019).

13 Wyrok Sądu Apelacyjnego w Białymstoku z dnia 7 grudnia 2017 roku, III AUa 434/17, LEX nr 2348388 (dostęp: 28.03.2019).

14 Dotyczy to także możliwości stosowania tak zwanego małego ZUS-u, proporcjonalnego do przychodu określonego w art. $18 \mathrm{c}$ u.s.u.s. 
Fakt, jak mało osób ma status twórcy lub artysty, znajduje odzwierciedlenie w statystykach organów rentowych udostępnionych na portalu statystycznym Zakładu Ubezpieczeń Społecznych. Na koniec czwartego kwartału 2018 roku wśród ubezpieczonych (osób fizycznych) podlegających ubezpieczeniom emerytalnym i rentowym według grup tytułów ubezpieczeń osoby prowadzące pozarolniczą działalność gospodarczą oraz osoby z nimi współpracujące to ogółem liczba 1542323 , w tym 1216054 deklarowało kwotę nie niższą niż 60\% kwoty przeciętnego miesięcznego wynagrodzenia, a 256714 w kwocie nie niższej niż 30\% przeciętnego miesięcznego wynagrodzenia. Natomiast liczba twórców i artystów w grupie osób prowadzących samodzielną pozarolniczą działalność gospodarczą to, co wymaga podkreślenia, 341 osób w skali całego kraju ${ }^{15}$. Dobrowolnemu ubezpieczeniu chorobowemu wśród tej samej grupy podlegało jedynie 193 twórców i artystów ${ }^{16}$. Nie wydaje się, że tylko tyle mamy w naszym kraju twórców i artystów. Dane te pokazują, że jedynie ich znikoma liczba decyduje się uzyskać taki status wykonywania działalności. Część twórców i artystów zatrudniona jest oczywiście w ramach stosunku pracy. Inni zakładają pozarolnicze działalności gospodarcze różnego rodzaju i korzystają z ulg, a w sytuacji utraty prawa do preferencyjnej składki z uwagi na nieregularność dochodów często kończą działalność. Jeszcze inni zatrudniają się dorywczo na umowy cywilnoprawne, zwłaszcza na umowy o dzieło, które są nieoskładkowane, nie zdając sobie sprawy, jakie to ma konsekwencje w zakresie nie tylko przyszłych świadczeń długoterminowych (emerytura, renta), lecz także krótkoterminowych (między innymi zasiłek chorobowy czy świadczenia z tytułu wypadku przy pracy).

Niewątpliwie trzeba stworzyć system finansowania ubezpieczeń zawodowych twórców i artystów, który odpowiadałby specyfice ich pracy, a zwłaszcza nieregularności zleceń i dochodów. Jest to o tyle istotne, że w systemie tak zwanej zdefiniowanej składki każdy okres nieopłacania składek negatywnie wpływa na wysokość prawa do emerytury. Sytuacją niepożądaną jest, żeby twórcy i artyści na starość zmuszeni byli zostać beneficjentami pomocy społecznej czy liczyli na bardzo ograniczone zapomogi z Funduszu Twórczości, gdyż nie będą mieli innego tytułu do otrzymania świadczeń. To niestety często spotyka osoby, które nie odprowadzały składek w przeszłości i aktualnie przechodzą na emeryturę.

Patrząc na rozwiązania funkcjonujące w innych państwach europejskich, wydaje się nieuniknione partycypowanie funduszy państwowych w składce twórców i artystów. Dla przykładu bardzo ciekawe i warte rozważenia pod względem potencjalnych zmian ustawodawczych jest rozwiązanie funkcjonujące w Niemczech. Ubezpieczaniami twórców i artystów zajmuje się Künstlersozialkasse (Kasa Artystów). Składki na ubezpieczenia emerytalne, opiekuńcze i zdrowotne są opłacane

15 Ubezpieczeni (osoby fizyczne) w ubezpieczeniach emerytalnym i rentowym według grup tytułów ubezpieczeń — stan na 31 grudnia 2018 roku, www. psz.zus.pl (dostęp: 28.03.2019).

16 Ubezpieczeni (osoby fizyczne) w ubezpieczeniu chorobowym według grup tytułów ubezpieczeń — stan na 31 grudnia 2018 roku, www. psz.zus.pl (dostęp: 28.03.2019). 
w połowie przez artystów i publicystów, którzy rzeczywiście stale i zarobkowo zajmują się sztuką i osiągają określony minimalny dochód, a w pozostałej części z dotacji budżetowej i środków (procenta przychodów), które każda instytucja korzystająca ze sztuki (galerie, muzea, wystawcy) ma obowiązek odprowadzać do tej kasy ${ }^{17}$. Z limitu osiągania minimalnego dochodu zwolnieni są młodzi twórcy w ciągu pierwszych trzech lat działalności. Co istotne, w przypadku zajścia ryzyka ubezpieczeniowego kasa redystrybuuje środki z poszczególnych funduszy na rzecz świadczeniobiorcy. Specjalny system zabezpieczenia społecznego twórców i artystów mający na celu stworzenie swoistego uprzywilejowania tej grupy zawodowej funkcjonuje także we Francji (La Maison des Artistes).

\section{PRACE NAD UREGULOWANIEM STATUSU TWÓRCY I ARTYSTY}

Postulaty dotyczące uregulowania statusu twórcy i artysty i stworzenia systemu wsparcia dla tej grupy zgłaszane są od lat przez środowiska artystyczne. Twórca tworzący przez pół roku instalację, która być może zostanie zakupiona przez jakiegoś pasjonata sztuki albo zostanie wystawiona w galerii sztuki, nie jest w stanie co miesiąc ponosić obciążeń w zakresie składek na ubezpieczenia społeczne, analogicznych do tych, które ponoszą przedsiębiorcy. Wydaje się, że dobrym rozwiązaniem, nad którym warto się pochylić, byłaby konstrukcja składki dzielonej, której część opłacana normalnie przez pracownika byłaby ponoszona przez twórcę, a część płacona przez pracodawcę ze stworzonego w tym celu specjalnego państwowego funduszu celowego. Stanowiłoby to zachętę dla potencjalnych adresatów do włączenia się do systemu, zasilając go jednocześnie nowymi członkami. Należałoby także poszukać źródeł finansowania w postaci dotacji budżetowej.

W 2015 roku odbył się zorganizowany w Toruniu przez Związek Zawodowy Twórców Kultury II Kongres Twórców Kultury Polskiej, w czasie którego zgłoszono postulat reformy statusu twórcy i artysty ${ }^{18}$. Także w latach 2017 i 2018 odbyło się wiele konsultacji środowiskowych w ramach Ogólnopolskiej Konferencji Kultury, podczas których starano się zidentyfikować wiele potrzeb i oczekiwań tej grupy zawodowej. Jednym z pilnych do uregulowania zagadnień jest właśnie kwestia zabezpieczenia społecznego twórców i artystów. Zgłoszono propozycje zmian systemowych w postaci utworzenia kasy artystów i twórców, w której uczestnictwo oparte byłoby na kryterium ekonomicznym - dochodzie brutto z pracy artystycznej przekraczającym corocznie modyfikowany pułap. Członkostwo w kasie związane byłoby z opłacaniem składek i da-

17 www.kuenstlersozialkasse.de (dostęp: 28.03.2019).

18 Zob. Raport o stanie polskiej kultury. Wnioski i postulaty Kongresu, www.zztk.pl (dostęp: 28.03.2019). 
wałoby wiele uprawnień i zabezpieczeń w wypadku przestojów w pracy, braku środków na ubezpieczenia społeczne czy początków pracy zawodowej19.

O tym jak ważne są postulaty środowisk artystycznych, świadczy rozpoczęcie prac nad projektem ustawy w Ministerstwie Kultury i Dziedzictwa Narodowego (dalej: MKiDN), która ma unormować status osoby zawodowo trudniącej się tego rodzaju działalnością. Stanowisko w tym zakresie MKiDN przekazało na zapytanie Rzecznika Praw Obywatelskich. W związku z tym, że ramy niniejszego opracowania nie pozwalają na szczegółowe przedstawienie projektu, warto zasygnalizować jego podstawowe założenia. Wstępny projekt ustawy o statusie artysty zawodowego ma zapewniać osobom zawodowo prowadzącym działalność twórczą lub artystyczną, a nieposiadającym innego tytułu do podlegania ubezpieczeniom społecznym wynikającego ze stosunku pracy, prowadzenia pozarolniczej działalności gospodarczej na podstawie przepisów ustawy z dnia 6 marca 2018 roku Prawo przedsiębiorców oraz prowadzenia działalności w ramach wolnego zawodu w rozumieniu art. 8 ust. 6 pkt 3 ustawy o systemie ubezpieczeń społecznych, prawo do opłacania wszystkich składek na ubezpieczenia społeczne i zdrowotne $\mathrm{w}$ wysokości analogicznej do tej odprowadzanej od minimalnego wynagrodzenia za pracę ${ }^{20}$. Ponadto artystom, których przeciętny miesięczny przychód byłby niższy niż przeciętne wynagrodzenie $\mathrm{w}$ gospodarce narodowej, miałyby przysługiwać dopłaty do składek na ubezpieczenie społeczne w wysokości dostosowanej do przychodu uzyskanego w poprzednim roku. Zgodnie z założeniami dopłaty mają być finansowane z Funduszu Wsparcia Artystów Zawodowych - państwowego funduszu celowego, którego operatorem będzie Narodowy Fundusz Artystów. Aktualnie wstępny projekt wspomnianej ustawy jest konsultowany z Zespołem Ekspertów Ogólnopolskiej Konferencji Kultury ${ }^{21}$. Proces legislacyjny wymaga jednak określenia przewidywanych kosztów zaproponowanych rozwiązań, co wymaga przede wszystkim oszacowania liczby potencjalnych adresatów. W związku z tym, że prace nad ustawą trwają i wiążą się z tym konieczne zmiany także $\mathrm{w}$ innych powiązanych aktach prawnych, należy poczekać na jej ostateczny kształt.

\section{ZAKOŃCZENIE}

Działalność zawodowa twórców i artystów w obecnym kształcie budzi uzasadnione wątpliwości. Analiza obowiązujących rozwiązań skłania do wniosków,

19 Co do szczegółów zob. W. Walczak, A. Rosochacki, Ogólna Konferencja Kultury. Kasa Artystów i Twórców. Projekt systemu, www.konferencjakultury.pl (dostęp: 30.12.2018).

20 Zob. Odpowiedź Wiceprezesa Rady Ministrów, Ministra Kultury i Dziedzictwa Narodowego z dnia 27 grudnia 2018 roku (Pismo DIK-WLA. 400.578.2018.MS) na pismo Rzecznika Praw Obywatelskich (pismo nr III. 7060. 158. 2016.AS z dnia 14 listopada 2018 roku) — www.rpo.gov.pl (dostęp: 28.03.2019).

21 Wstępny projekt ustawy z dnia 10 grudnia 2018 roku o statusie artysty zawodowego został ostatnio udostępniony wyłącznie do celów informacyjnych na stronie www.www.zztk.pl (dostęp: 28.03.2019). 
że nie do końca jasna i wymagająca doprecyzowania jest sama konstrukcja ubezpieczenia społecznego tej grupy zawodowej. Także rola Komisji do Spraw Zaopatrzenia Emerytalnego Twórców i jej orzeczeń budzi rozbieżności w interpretacji, co stara się ujednolicać orzecznictwo. Specyfika działalności twórców i artystów związana jest $\mathrm{z}$ indywidualnym i twórczym charakterem ich pracy, a jej wynik często nie pozwala osiągać stałych dochodów. $Z$ uwagi na to za słuszne należy uznać argumenty, że nie można traktować tej grupy zawodowej tak samo jak każdego innego przedsiębiorcy, a jak się okazuje, często jest ona pozbawiana nawet prawa do ulg, z których korzystają inne osoby prowadzące pozarolniczą działalność gospodarczą. To powoduje, że niewątpliwie de lege ferenda potrzebne jest stworzenie odrębnego systemu ubezpieczenia społecznego zawodowych twórców i artystów, który zachęcałby potencjalnych adresatów znajdujących się obecnie poza systemem do uczestnictwa $\mathrm{w}$ nim. Na aprobatę w tym względzie zasługują prace legislacyjne w Ministerstwie Kultury i Dziedzictwa Narodowego, które w przyszłości mają doprowadzić do jego powstania.

\section{SOCIAL INSURANCE OF PROFESSIONAL AUTHORS AND ARTISTS - SELECTED ISSUES}

\section{Summary}

Creative and artistic activity in the context of being the subject of social insurance raises a lot of controversy. It is a result of the fact of its specificity related to the irregularity of the work and income combined with the contribution charges at the level of entrepreneurs. The author analyzes and assesses the current legal regulations related to social insurance of professional authors and artists, in particular the role of the decision of a commission determining when such activity is commenced and its impact on the arising of the insurance obligation and the right to benefits. In addition, the author presents and discusses the proposed changes in the scope of including this group in a separate social insurance system that assumes the establishment of suitable support mechanisms which will allow for the real participation of these people in the system.

Keywords: social insurance, professional authors and artists, separate insurance system

\section{BIBLIOGRAFIA}

Gudowska B., [w:] Ustawa o systemie ubezpieczeń spolecznych. Komentarz, red. B. Gudowska, J. Strusińska-Żukowska, Warszawa 2011.

Zieleniecki M., Zakres podmiotowy ubezpieczenia społecznego, [w:] Ubezpieczenia społeczne dawniej $i$ dziś. W 80-lecie uchwalenia ustawy o ubezpieczeniu społecznym, red. Ł. Kucharczyk-Rok, O. Rawski, A. Żołna, Wrocław 2013. 